\title{
The Impact of Financial Malpractice on Service Delivery: A Conceptual Examination of Literature
}

\author{
Wiston Mbhazima Baloyi ${ }^{\circledR}$ \\ Lourens Johannes Erasmus Beyers ${ }^{2}$

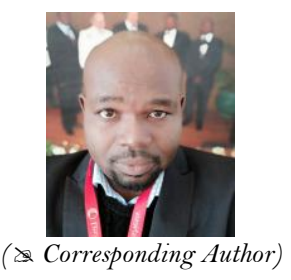

\begin{abstract}
This paper argues that financial malpractice has not always been remedied in the public sector. Legislation that governs financial administration in the public sector is, thus, being disregarded. Officials continuously engage in unwanted expenditure (i.e. unauthorised, irregular, fruitless and wasteful expenditure) and no action is taken against them. The purpose of this paper was to probe the impact of financial malpractice by public officials as an impediment to service delivery. The methodological approach of this paper was the conceptual examination of literature which ultimately lead to proposed strategy measures towards financial malpractice and service delivery. This paper finds that officials unethically pursue their self-interest in enriching themselves by looting the government funds and neglecting the focus of enhancing service delivery. Consequently, this has relegated the impoverished citizens to a crisis situation. The lack of proper planning and the embezzlement of public funds have both been identified as factors that impede service delivery. This paper suggests that the government should tighten its internal control measures and reinforce compliance with the applicable laws and regulations. Furthermore, it suggests that officials should be held liable for any financial malpractice and, therefore, penalties for financial misconduct should be instituted against them. Lastly, government should provide comprehensive training and awareness programmes on financial malpractice and financial misconduct.
\end{abstract}

Keywords: Financial malpractice, Financial misconduct, Irregular expenditure, Unauthorised expenditure, Service delivery, Corruption.

Citation | Wiston Mbhazima Baloyi; Lourens Johannes Erasmus Beyers (2019). The Impact of Financial Malpractice on Service Delivery: A Conceptual Examination of Literature. Asian Journal of Social Sciences and Management Studies, 6(2): 23-29.

History:

Received: 1 July 2019

Revised: 6 August 2019

Accepted: 9 September 2019

Published: 3 October 2019

Licensed: This work is licensed under a Creative Commons

Attribution 3.0 License $(\mathrm{cc}) \mathbf{E}$

Publisher: Asian Online Journal Publishing Group
Acknowledgement: Both authors contributed to the conception and design of the study.

Funding: This study received no specific financial support

Competing Interests: The authors declare that they have no conflict of interests.

Transparency: The authors confirm that the manuscript is an honest, accurate, and transparent account of the study was reported; that no vital features of the study have been omitted; and that any discrepancies from the study as planned have been explained.

Ethical: This study follows all ethical practices during writing.

\section{Contents}

1. Introduction

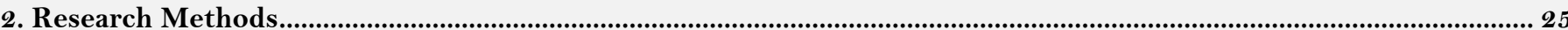

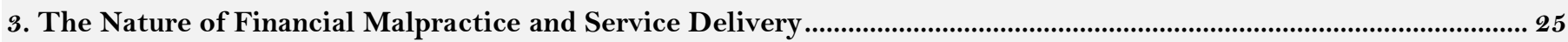

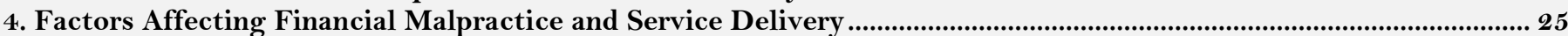

5. Techniques for Enhancing Service Delivery and Inhibiting Financial Malpractice ..................................................... 27

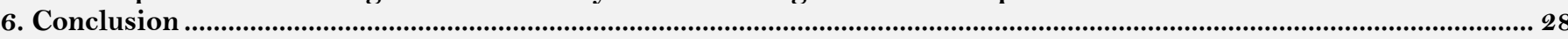

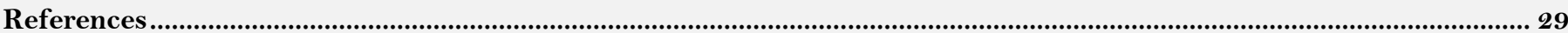




\section{Contribution of this paper to the literature}

The purpose of this paper was to probe the impact of financial malpractice by public officials as an impediment to service delivery.

\section{Introduction}

The global leaders adopted the 2030 agenda for sustainable development to eradicate poverty and ensure that all citizens live in harmony (Giamatteo and Valdivia, 2018). The view was to accelerate service delivery the lack of which is a serious crisis around the globe. This predicament arises on the account of lack of proper financial management expertise and engagement into fraudulent and corrupt activities by public officials (Booranakit et al., 2018); (Meyer, 2018). Hence, the effective and efficient management of public finances should lead to good financial governance and reduction of financial malpractice. This research paper intended to examine the impact of financial malpractice by public officials as an impediment to service delivery.

There are laws that govern public finances and administration; and public officials are obliged to adhere to them. However, in some instances these are disregarded. In most cases, the examples of financial malpractice emanate from unethical procurement practices and non-compliance with applicable laws by public officials. According to Mazibuko and Fourie (2017) the unethical supply chain practices arise from "uncompetitive or unfair procurement processes, inadequate contract management, awards to close family members of employees, lack of documentation to the awards and awards to employees of government institutions". This situation has been declared a major contributor to adverse audit outcomes in the public sector (Auditor-General South Africa (AGSA), 2017). Furthermore, it has accelerated the incurring of irregular expenditure, unauthorised expenditure, corruption, fraud and bribery activities.

Accordingly, the research enquiry that is fundamental to this paper is: How does financial malpractice impact service delivery? Given this research enquiry, the objective of this research paper was to examine the impact of financial malpractice on service delivery. The paper suggests that officials should be held liable for any financial malpractice and, therefore, penalties for financial misconduct should be instituted against them. Furthermore, leadership in the public sector should foster the compliance with applicable policies and procedures. Hence, improved service delivery and sound financial management are both the cornerstone of the public service.

This research paper is significant in the Republic of South Africa, the African Continent and the world at large, in that it suggests the strategies or techniques that public officials could apply to eliminate the occurrence of financial malpractice and thus enhance service delivery to the citizens. Further, the policy makers in government could employ the suggestions of this paper to develop the prescripts that would provide more oversight into the persistent financial malpractice which has an adverse impact on service delivery. This research paper is motivated by the significant practical challenges (e.g. shortage of water, shelter and sanitation), that are encountered on a daily basis by the society at large. For example, the pervasive service delivery protests are evident in most of the countries around the globe, including the Republic of South Africa.

Consequently, politics plays a pivotal role in the public service. Public officials continuously engage in political activities. This often leads to service delivery being compromised. Kasum (2009) advocates that "the rate at which public office holder in developing economies perpetrate financial malpractice is dangerously alarming". It is evident that there is a consistent failure in the ability of public service to comply with and implement public service policies effectively and efficiently (Department of Public Service and Administration (DPSA)-RSA, 2018). Therefore, given the current situation, a rapid intervention and remedy by public service is required. Although, several studies have focused on service delivery, this research paper embarks on a conceptual examination of the literature relating to financial malpractice and its potential references to service delivery. Succinctly, it intended to examine how financial malpractice might impact service delivery, with the view of alleviating poverty and social distress among the citizens. For the purpose of this paper, the concepts of public sector and public service are used interchangeably.

This research paper is structured as follows: the next section illustrates the research methods. It is followed by a discussion of the nature of financial malpractice and service delivery. The next section is the examination of the factors that are associated with financial malpractice and service delivery. Techniques for enhancing service delivery and inhibiting financial malpractice are also discussed; and lastly, the research paper culminates with conclusions.

Table-1. Different approaches and methods used to probe the impact of service delivery.

\begin{tabular}{|c|c|c|}
\hline Author & Approach & Findings \\
\hline Akpan (2019) & $\begin{array}{l}\text { A quantitative using survey design was } \\
\text { utilised to investigate the harnessing of e- } \\
\text { governance for enhanced public service } \\
\text { delivery in Nigeria }\end{array}$ & $\begin{array}{l}\text { The implementation of e-governance } \\
\text { would ensure enhanced efficiency in } \\
\text { performing the administration in the } \\
\text { public sector }\end{array}$ \\
\hline Mfuru et al. (2018) & $\begin{array}{l}\text { A mixed methods approach was used to } \\
\text { explore the impact of political interference in } \\
\text { public administration }\end{array}$ & $\begin{array}{l}\text { The major findings of this study reveals } \\
\text { that public officials are unable to carry } \\
\text { their mandates effectively due to political } \\
\text { interferences }\end{array}$ \\
\hline Dzomira (2017) & $\begin{array}{l}\text { A qualitative approach using interpretative } \\
\text { approach was applied to probe financial } \\
\text { accountability and governance in an emerging } \\
\text { economy }\end{array}$ & $\begin{array}{l}\text { The results suggests that South African } \\
\text { public financial governance should put } \\
\text { measures to erode the occurrence of } \\
\text { irregular, fruitless and wasteful and } \\
\text { unauthorised expenditure }\end{array}$ \\
\hline Sibanda (2017) & $\begin{array}{l}\text { A conceptual examination of literature was } \\
\text { employed to investigate the control, ethics } \\
\text { and accountability in the financial } \\
\text { management performance of municipalities in } \\
\text { the Eastern Cape }\end{array}$ & $\begin{array}{l}\text { The results proposed that public finance } \\
\text { should be conceptualised to embrace ethics } \\
\text { and accountability in the public sector }\end{array}$ \\
\hline
\end{tabular}




\section{Research Methods}

The methodological approach employed in this paper was the conceptual examination of existing literature that ends with proposed strategies or techniques that could be implemented to reduce financial malpractice in the public sector, and thus, enhance service delivery. Different approaches and methods were utilised to probe the impact of service delivery on society. Several studies focused on the empirical researches where in-depth interviews and selfadministered researches were done by various scholars to investigate service delivery. In addition, conceptual studies were conducted to probe the subject of service delivery and accountability (Jashari and Pepaj, 2018); (Mazibuko and Fourie, 2017) service delivery and financial accountability (Sibanda, 2017); (Ngwakwe, 2012).

As highlighted above, different approaches and methods were used to investigate the impact on service delivery. Some of these approaches are outlined Table 1.

\section{The Nature of Financial Malpractice and Service Delivery}

There is an emerging trend of government departments failing to manage their finances properly (AGSA, 2017). Financial malpractice is rooted in the manifestations of fraud, corruption and bribery activities in the public sector which are universally rampant (Kasum, 2009). In addition, it focuses on the phenomenon of fruitless and wasteful, irregular and unauthorised expenditure proliferating on a daily basis. In the context of this paper, financial malpractice refers to reckless financial activities committed by public officials that obstruct the enhancement of service delivery to the citizens. Financial malpractice is viewed as being a fundamental impediment to service delivery. Therefore, this research paper has intended to examine the impact of financial malpractice by those public officials as factor which is crucial to the provision of enhanced service delivery.

According to Naidoo (2012) service delivery refers to "the implementation of public policies aimed at providing services to the citizens". Akpan (2019) defines service delivery as the "provision of goods which are tangible, and services which are intangible to the public". Therefore, in this paper, service delivery refers to the provision of integrated and better services to the citizens of the country. The concepts of financial malpractice and service delivery are irreconcilable because the manifestation of financial malpractice in the public sector impedes the delivery of services to the citizens. In other words, the two concepts are pointing in different directions, that is, they are two variables which oppose each other. However, public officials persist in committing financial malpractice, incurring irregular, fruitless and wasteful expenditure (Dzomira, 2016). This persistent irregular conduct has been escalating as a result of "failure by management to take effective and appropriate disciplinary steps against officials who made or permitted unauthorised, irregular or fruitless and wasteful expenditure” (Phago, $2015)$.

Sustainable service delivery has been a hurdle in the world at large (Giamatteo and Valdivia, 2018). The lack of financial accountability in the public sector has impeded the success of service delivery (Mutuma et al., 2017). To support this statement, Mazibuko and Fourie (2017) states that "the public sector needs to improve the efficiency of managing public finances". This can enable the governments to speed up the service delivery process and achieve the long-term goals.

\section{Factors Affecting Financial Malpractice and Service Delivery}

Various challenges in the society (including protests, the malicious damage of State goods; political unrest and so forth) have emerged due to lack of service delivery. These irregularities have emanated from a lack of devotion and commitment by the public officials in serving their communities. However, solutions could be devised to mend the status quo within the public sector. In the main, service delivery depends on good financial governance, and effective allocation and distribution of scarce resources. In this paper, the researchers identify the number of factors that affects financial malpractice and service delivery, whether negative or positive. Thus, this research paper finds the following:

- Lack of financial capacity.

- Unfair public procurement and supply chain management.

- Inappropriate planning.

- Improper delegation of authority.

- Embezzlement of public funds.

- Lack of internal control systems.

- Corruption.

- Fraud.

- Political interference.

These factors are actually interlinked in such a way that one factor could well influence the other. These are discussed below.

\subsection{Lack of Financial Capacity}

The origin of financial malpractice lies in the absence of expertise required to administer public finances. Lack of appropriate expertise has been reported as an obstacle to effective administration of public finances (Sibanda, 2017); (Saka, 2016); (Phago, 2015); (Dzomira, 2015); (Ngwakwe, 2012). Public officials are appointed to higher positions based on their political affiliation and interference (Mfuru et al., 2018). In essence, their political status is paramount in pursuing their self-interest and neglecting the needs of the society (Thomas, 2016). The Independent (2016) states that the selection panels should contain an independent element, to increase objectivity and public credibility. Furthermore, this independent element should embark on constant standard setting and observations that would enhance and sustain public confidence in the appointments process.

Consequently, due to incompetence, public officials are unable to take informed decisions. Furthermore, Dzomira (2016) posits that the lack of financial management skills among public officials significantly impedes efficient service delivery which leads to maladministration in the public service. In addition, a study by Edoun 
(2015) asserts that "public enterprises are the channel by which political leaders redistribute wealth by giving employment to comrades who lack the necessary skills and knowledge to manage”. Insufficient accounting skills among politicians results in intensification of corruption and fraud, and thus unclean audit findings (Meyer, 2018); (Sibanda, 2017); (Masiloane and Dintwe, 2014); (Naidoo, 2012). Therefore, politicians end up embezzling the State funds.

\subsection{Unfair Public Procurement and Supply Chain Management}

Supply chain management entails the process of acquiring products and services at the most affordable costs (Ngwakwe, 2012). It includes, amongst others, units such as procurement, assets, transport and logistics. Public procurement has been identified as being pivotal to improved service delivery as huge budgets are allocated to it. Ngwakwe (2012) argues that the non-existence of openness and transparency in public procurement has led to the misuse of funds on the African Continent. Hence, non-compliance with the applicable policies governing public supply chain and procurement processes has triggered a great deal of irregular and fruitless expenditure in the public service (Mazibuko and Fourie, 2017); (Dzomira, 2017); (Naidoo, 2012). Again, these unethical procurement practices include employees who are doing business with government without the necessary declarations (AGSA, 2017); (Masiloane and Dintwe, 2014). This happens as a result of insufficient internal control systems in the public sector.

\subsection{Inappropriate Planning}

Planning is the first portion of management functions; which is followed by organising, leading and controlling (Mfuru et al., 2018). Therefore, the executives and management need to pay careful attention to planning. In the context of the public sector, planning is in the form of strategic planning sessions in which the budgeting allocations of scarce resources to various programmes are contemplated (Sibanda, 2017); (Saka, 2016). This activity is undertaken by the executives of the department. In the main, the participants are likely to be politicians and this has an adverse influence on the processes. The process requires knowledgeable officials who understand the financial perspectives of the public service. The significance of financial planning in the public service cannot be overlooked as service delivery depends on sound financial management.

The Service Delivery Improvement Planning (SDIP) becomes crucial during the planning stage. Essentially, SDIP facilitates the commitment of government institutions to continuous service delivery improvement mechanisms that intend to enhance the quality of actual service provided (DPSA-RSA, 2018). In order to ensure continuous improvement, government institutions should establish SDIP and ensure its successful implementation. The SDIP should be aligned with the long-term objectives as highlighted in the strategic plan of the government institution.

\subsection{Improper Delegation of Authority}

According to Edoun (2015) delegation of authority entails "the shifting of management responsibilities from the center to the lower level, but the center retaining the overall control of powers". Public officials on the higher authority tend to abuse these powers for their own personal interests and gain, and to neglect the needs of the vulnerable citizens (Thomas, 2016). Although there are legislative frameworks and policies that govern public financial management including delegation of authority in the public service, they are neglected. Thus, the accounting officer of the government department should establish an explicit system of delegation of authority to improve operational standards and "provide adequate checks and balances" (Sibanda, 2017).

\subsection{Embezzlement of Public Funds}

The lack of good financial governance and continuous incurring of unwanted expenditure both remain as challenge that obstruct service delivery (Dzomira, 2017). This resulted in the mismanagement of public funds and thus, maladministration in different government departments. The lack of accountability in public finances has been accompanied by irregular procurement of goods and services and unaccounted public funds (AGSA, 2017); (Dzomira, 2017); (Dzomira, 2017); (Saka, 2016); (Naidoo, 2012). In addition, public officials have exploited their ranks by utilising public funds for personal benefit (Edoun, 2015). As a result, poor compliance with applicable rules and regulations has been evident in the inability to manage public funds (AGSA, 2017). This has relegated service delivery and left vulnerable citizens in a dire situation.

\subsection{Lack of Internal Control Systems}

Ample internal control measures should be in place to direct the functions on the daily basis. The research findings by Dzomira (2017) reveal that inadequate financial governance in the Republic of South Africa is continuing to ensure the incurring of unauthorised expenditure, irregular expenditure and, fruitless and wasteful expenditure. For example, it has been noted that Limpopo Province, amongst other provinces, has contributed significantly to the rise of irregular expenditure (AGSA, 2017).

The leaders in the public service tend to act based on their best interest and ignore compliance with applicable legislation. They engage in fraudulent activities by manipulating the systems for their personal gain and at the expense of the public; and no remedial actions are being taken against them. Hence service delivery suffers and the protests continue to happen in the society. Dzomira (2017) argues that various public agencies still experience challenges in relation to the evaluation of governance structures and agreements.

\subsection{Corruption}

Ngwakwe (2012) states that corruption is a "cancer that appears to be endemic in African public service". According to Mazibuko and Fourie (2017) public service institutions are still experiencing challenges of insufficient control over contract performance and assessment. This lack of control creates a loophole and possibility for escalating corruption. Thomas (2016) argues that corruption is a "consequence of the nexus between bureaucracy, politics and criminals". Furthermore, corruption creates economic obstacles in the public service in that public 
officials redirect public funds for their own personal gains and fail to render services to the communities (Thomas, 2016). This has placed impoverished citizens in a crisis situation. Therefore, good governance is an essential factor in combating corruption in the public sector (Meyer, 2018); (Booranakit et al., 2018); (Jashari and Pepaj, 2018); (Dzomira, 2017).

According to Sibanda (2017) corruption leads to "public funds being misused, applied to benefit a select individual or entity, or results in potential public funds being diverted from government revenue to private income". The Anti-Corruption Resource Centre (4U Guide) (2019) undertook the study to measure corruption in the public sector. The study was based on the Global Corruption Barometer which includes Latin America and Africa geographical areas. The ACRC (2019) conducted a research on corruption statistics and the measurement of corruption as set out Table 2 .

Table-2. Corruption related statistics.

\begin{tabular}{|c|c|c|}
\hline Type & Description & Examples \\
\hline $\begin{array}{c}\text { Administrative } \\
\text { statistics }\end{array}$ & $\begin{array}{l}\text { Characteristics of government } \\
\text { or its performance relevant to } \\
\text { corruption or anticorruption } \\
\text { outcomes }\end{array}$ & 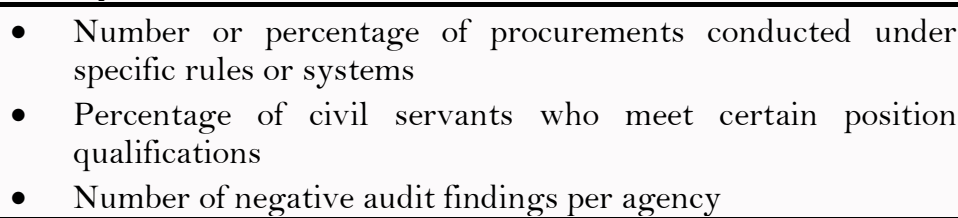 \\
\hline $\begin{array}{c}\text { Criminal or legal } \\
\text { statistics }\end{array}$ & $\begin{array}{l}\text { Data on corruption complaints, } \\
\text { investigations, prosecutions, } \\
\text { convictions }\end{array}$ & $\begin{array}{l}\text { - Number of corruption arrests, investigations by a specific } \\
\text { agency } \\
\text { - } \quad \text { Number of corruption convictions } \\
\text { - Ratio of arrests to convictions }\end{array}$ \\
\hline $\begin{array}{c}\text { Population } \\
\text { surveys and user } \\
\text { surveys }\end{array}$ & $\begin{array}{l}\text { Survey data on corruption } \\
\text { perceptions or experience (also } \\
\text { called victimisation surveys) }\end{array}$ & $\begin{array}{ll}\text { - } & \text { Regional barometer surveys } \\
\text { - } & \text { Global corruption barometer (experience survey) } \\
\text { - } & \text { Surveys of population sub-groups (e.g., enterprise surveys, ad } \\
& \text { hoc user surveys) }\end{array}$ \\
\hline
\end{tabular}

\subsection{Fraud}

Dzomira (2015) posits that government departments should ensure sound governance of risks and fraud, and also the fraud prevention plan needs to be regularly updated. Generally, fraud relates to unethical procurement processes which include amongst others, unjust procurement practices, insufficient contract administration and the awarding of tenders to relatives and friends (Mazibuko and Fourie, 2017); (Masiloane and Dintwe, 2014); (Naidoo, 2012). In addition, fraud practices should be avoided at all cost and the public sector should develop and implement coercing policy that deals with risks associated with fraudulent activities (Ngwakwe, 2012). Mazibuko and Fourie (2017) postulate that the manifestation of fraud in the public sector has an adverse effect on the citizens and lead to service delivery being compromised. However, the lack of skills intensifies the manifestation of risks relating to procurement processes and thus, fraud. Furthermore, the lack of fraud prevention strategies and policies in the government departments disrupts the process of enhancing better service delivery (Sibanda, 2017); (Phago, 2015); (Naidoo, 2012).

\subsection{Political Interference}

The appointments of public office bearers in the public sector should be subject to the overriding principle of merit, so an independent body should set standards and monitor compliance (The Independent, 2016). The public service functions under bureaucratic mode of operation or modus operandi. Therefore, the accounting officers have power and control over budgets, supply chain management and other activities. However, financial capacity has always been a hurdle in the public sector. The lack of financial capacity and political interference makes it difficult for public officials to administer public finance (Meyer, 2018); (Mfuru et al., 2018); (Naidoo, 2012). To support this, Mfuru et al. (2018) assert that political interference in the public service has resulted in illegitimate decisionmaking processes, fruitless budget allocations and ignorance of applicable laws and regulations.

The Chief Financial Officer (CFO) of the government departments has to ensure effective and efficient systems of financial and internal control are in place. However, in some instances, the CFOs are dismissed from their duties even before the end of their tenure due to political interferences. This statement is supported by Phago (2015) that "the high vacancy and turnover rates of accounting and chief financial officers remain a cause for concern from the Auditor General's Office”.

\section{Techniques for Enhancing Service Delivery and Inhibiting Financial Malpractice}

This paper provide a discussion of the suggested techniques that could be applied to enhance service delivery and inhabit financial malpractice. These are discussed below.

\subsection{Transparent Supply Chain Management Systems}

Challenges with supply chain management have remained one of the key contributors to poor audit outcomes (AGSA, 2017). Supply chain management is the heart of service delivery and it is essential to recognise that it is imperative. The high rate of irregular expenditure in the public sector stems from the governance challenges emanating from the poor supply chain activities (Dzomira, 2017); (Mazibuko and Fourie, 2017); (AGSA, 2017). A sound procurement system in the public sector is characterised by aspects such as responsiveness, openness and accountability (Mazibuko and Fourie, 2017); (Sibanda, 2017); (Naidoo, 2012) which are currently not effective. Mazibuko and Fourie (2017) provides for the continuous vigilance in respect to procurement practices in the public sector. These include the following:

- Reinforcing ethical behaviour as pointed out by applicable prescripts. 
- Ensuring ample procurement planning including evaluation of risks.

- Operating in a transparent way such as openly sharing procurement plans.

- Ensuring supervision, including regular spot checks of procurement transactions.

- Reporting instances of fraud and corruption emanating from procurement activities.

\subsection{Transparency and Accountability in Public Administration}

Masiloane and Dintwe (2014) argue that the reduction of the bureaucratic modus operandi enables the public sector to enhance openness and accountability. Openness and transparency in the public service play a huge role in the way in which the public service operates and supports the high level of approachability, efficiency and effectiveness to various stakeholders (Jashari and Pepaj, 2018); (Naidoo, 2012). Transparency refers to "unfettered access by the public to timely and reliable information on decisions and performance in the public sector" (Jashari and Pepaj, 2018). Transparency in the public service is maintained by means of implementing modernised systems of Information Communication and Technology (ICT). Therefore, citizens should know where to get information about the services, and how those services are rendered by the public sector.

Transparency is at the heart of honesty and trustworthiness in the public sector and it improves public confidence and support (Sibanda, 2017); (Ngwakwe, 2012). To support this statement, the implementation of binding ethics in public supply chain practices is crucial for the enhancement of transparency and accountability in the public sector (Booranakit et al., 2018); (Mazibuko and Fourie, 2017). However, in order to promote ethical conduct in the public sector and tackle the issues and allegations relating to accountability, the following should be contemplated (Ngwakwe, 2012):

- Institute a restricted hotline for reporting illegal behaviour, including the abuse of authority.

- Reinforce compliance with the applicable legal frameworks by ensuring standards of conduct.

- Convey information concerning disciplinary cases.

- Develop grievance procedures outside formal channels through the Office of the Joint Ombudsperson.

- Formalise an obligatory code of conduct/ethics capacity for all staff.

\subsection{Effective Internal Control and Audit Systems}

Internal audit systems are paramount to the achievement of long-terms objectives of the public service institutions. The internal audit and audit committees play a pivotal role in ensuring that they recognise any contravention with applicable laws and regulations (Sibanda, 2017). Tight internal control systems enable the public sector to ensure reliability, and this inspire public officials to report any arising irregularities resulting from corrupt activities (Masiloane and Dintwe, 2014). Internal audits pave the way for the external audit and help earmark the areas of administration that require urgent attention. It should thus be taken seriously in the public sector as it provide a preliminary audit just before the external audit commences. As a part of strengthening internal control, leadership in the public sector needs to develop and effectively implement the anti-corruption policy and strategy to diminish the spreading of corruption and fraud (Masiloane and Dintwe, 2014).

\subsection{Effective Information Communication and Technology}

Information Communication and Technology (ICT) is the "science and activity of moving data digitally" (Lucas, 2016). Information technology systems should be enhanced and customised to specific areas of service delivery, including financial management and its delegation of authority (Jashari and Pepaj, 2018). Further, it is crucial for the public sector to deliver its mandates efficiently by constantly strengthening its systems and processes. Ngwakwe (2012) asserts that the efficient use of Information Communication and Technology (ICT) necessitates the provision of comprehensive training and the development of all staff, including finance staff, in the public service to ensure effective public administration. For example, ICT systems can be enhanced in such a way that they track and trace the records of service delivery. The business process re-engineering was applied by the Department of Justice and Constitutional Development of the Republic of South Africa to enhance efficiency and responsiveness to service delivery pertaining to court administration (Lucas, 2016). In addition, the implementation of e-governance tool could help accelerate the process of delivery of services to the citizens (Akpan, 2019); (Salam, 2017). Akpan (2019) defines e-governance as "the application of ICT to improve the delivery of services in the public service to attain transparency, accountability, timeliness and efficiency”.

\subsection{Implement Corrective Measures against Perpetrators}

Financial misconduct should be instituted against the public officials who continuously incur irregular, fruitless and unauthorised expenditure. Furthermore, public officials should be held liable and accountable for committing corruption, fraud and bribery-related activities. The financial skills in the public sector have been perceived as being scarce, thus the public sector should implement comprehensive training and development programmes to equip their staff. These include, but are not limited to the provision of in-house training, mentoring and outsourcing of training initiatives. Staff rotation to different sections could also help to curb the acts of financial malpractice in the public sector.

In their study, Masiloane and Dintwe (2014) contend that "if there are sufficient internal controls and sufficient number of perpetrators are apprehended for corruption and punished adequately, there is a likelihood that the prospective perpetrators will stop immediately". In addition, public awareness with regard to corrupt activities can help diminish its occurrence.

\section{Conclusion}

This paper has examined the impact of financial malpractice on service delivery. It has emphasised that financial malpractice is an obstruction to enhanced service delivery. It has uncovered various factors associated with financial malpractice and service delivery. These include the lack of financial capacity, unfair public 
procurement and supply chain management, inappropriate planning, improper delegation of authority, the embezzlement of public funds, the lack of internal control systems, corruption, fraud and political interference. Furthermore, this paper has proposed the techniques for enhancing service delivery and inhibiting financial malpractice. These include, amongst others, transparent supply chain management systems, transparency and accountability in public administration, effective internal control and audit systems and effective information communication and technology. This paper finds that officials unethically pursue their self-interest in enriching themselves by looting government funds and neglecting the focus of enhancing service delivery. Such activities have relegated the impoverished citizens to a crisis situation. The lack of proper planning and the mismanagement of finances have both been identified as factors that impede service delivery.

This paper suggests that the government should tighten its internal control measures and reinforce compliance with the applicable laws and regulations. Furthermore, the fruitful allocation and disbursement of the scarce resources is still a challenge in the public sector and hampers the provision of service delivery. It also suggests that officials should be held liable for any financial malpractice and thus, penalties for financial misconduct should be instituted against them. Lastly, government should provide comprehensive training and awareness programmes focused on financial malpractice and financial misconduct.

\section{References}

Akpan, A.G., 2019. Harnessing e-governance for quality public service delivery in Akwa Ibom State, Nigeria: Benefits and challenges. European Journal of Business and Social Sciences, 7(5): 1117-1127.

Anti-Corruption Resource Centre (4U Guide), 2019. Guide to using corruption measurements and analysis tools for development programming.

Auditor-General South Africa (AGSA), 2017. Overall audit outcomes.

Booranakit, N., P. Tungkunanan, D. Suntrayuth and J. Ebenezer, 2018. Good governance of Thai local educational management. Asia-Pacific Social Science Review, 18(1): 62-77.

Department of Public Service and Administration (DPSA)-RSA, 2018. Service delivery improvement plan.

Dzomira, S., 2015. Governance and fraud risk management in the public sector in South Africa. Public and Municipal Finance, 4(3): 25-36.

Dzomira, S., 2016. Espousal of combined assurance model in South Africa's public sector. Public and Municipal Finance, 5(4): 23-30.Available at: https://doi.org/10.21511/pmf.05(4).2016.03.

Dzomira, S., 2017. Financial accountability \& governance in an emerging economy. Corporate Ownership \& Control, 14(3): $204-218$.

Edoun, E.I., 2015. The implication of governance in the management of public enterprises in Africa. Journal of Governance and Regulation, $4(2): 7-14$.

Giamatteo, L. and A.O. Valdivia, 2018. The 2030 agenda for sustainable development: How to get students involved? World Journal of Educational Research, 5(4): 358-367.Available at: https://doi.org/10.22 158/wjer.v5n4p358.

Jashari, M. and I. Pepaj, 2018. The role of the principle of transparency and accountability in public administration. University of Pecs. Administration, 10(1): 60-69.

Kasum, A., 2009. The relevance of forensic accounting to financial crimes in private and public sectors of third world economies: A study from Nigeria. In Proceedings of The 1st International Conference on Governance Fraud Ethics and Social Responsibility.

Lucas, T., 2016. The application of business process re-engineering systems to enhance service delivery in the public sector. European Journal of Research in Social Sciences 4(7): 13-22.

Masiloane, D. and S. Dintwe, 2014. Developing an anti-corruption strategy for the South African public sector. Journal of Public Administration, 49(1): 180-198.

Mazibuko, G. and D.J. Fourie, 2017. Manifestation of unethical procurement practices in the South African public sector. African Journal of Public Affairs, 9(9): 106-117.

Meyer, D., 2018. Predictors of good governance and effective government management: The case of Poland. Polish Journal of Man agement Studies, 18(1): 206-217.

Mfuru, A.W., A.C. Sarwatt and G. Kanire, 2018. The impact of political interference in public administration in Kibaha Town council. Global Journal of Political Science and Administration, 6(4): $21-31$.

Mutuma, M.N., M. Iravo, E. Waiganjo and J. Kihoro, 2017. Moderating effect of government policies on relationship between shared responsibility and service delivery by county government workers in Kenya. International Journal of Academic Research in Business and Social Sciences, 7(4): 713-731.Available at: https://doi.org/10.6007/ijarbss/v7-i4/2863.

Naidoo, G., 2012. The critical need for ethical leadership to curb corruption and promote good governance in the South African public sector. Journal of Public Administration, 47(3): 656-683.

Ngwakwe, C., 2012. Public sector financial accountability and service delivery. Journal of Public Administration, 47(Special issue 1): 311 -329.

Phago, K.G., 2015. Public human resource practices and performance management development systems in the public sector. Journal of Public Administration, 50(Special issue 1): 620-622.

Saka, G.O., 2016. Public finance legislation and accountability for public finances in Uganda's rural health sector. Home Business Journal, 15: $1-16$.

Salam, M.A., 2017. E-governance for good governance: Experiences from public service delivery. Methodology, 7(3): 26-29.

Sibanda, M.M., 2017. Control, ethics and accountability in the financial management performance of Eastern Cape municipalities. Journal of Public Administration, 52(2): 313-339.

The Independent, 2016. Public appointments are finally made on talent, not connections - but we must fight to keep it that way.

Thomas, S., 2016. A critical analysis of controls on maladministration and corruption in India. International Journal of Legal Insight, 1(1): $31-46$. 